\title{
Spesialisering av leger når kortsiktigheten råder
}

Foretaksreformen fra 2002 ga ikke bare et nytt rammeverk for helsevesenet, det markerte også starten på en periode med stadig nye omstillinger, sammenslåinger og omorganiseringer. Jonas Gahr Støre gikk så langt at han i sin sykehustale tidligere i år slo fast at omstillinger er hverdagen i norsk helsevesen (1).

Med foretaksreformen kom lov om helseforetak som slår fast at sykehusenes oppgaver er behandling av pasienter, forsking, utdanning av helsepersonell og opplæring av pasienter og pårørende. Innsatsstyrt finansiering (ISF) var allerede innført i 1997, men ble et viktig styringsverktøy i de nye helseforetakene. Denne ordningen innebærer at helseforetakene nå finansieres gjennom en basisbevilgning på $60 \%$ av den totale økonomiske rammen, mens de resterende $40 \%$ ikke tilføres før pasienten er behandlet. Inntektene som utløses ved aktivitet er i all hovedsak knyttet til diagnose, gjennomførte prosedyrer, alder, kjønn og utskrivningsstatus. På bakgrunn av disse parametrene klassifiseres pasienten i en diagnoserelatert gruppe (DRG). DRG-grupperingene er kostnadsvektet slik at foretakene skal få finansiert pasientbehandlingen med utgangspunkt i kompleksiteten i pasientens tilstand og behandling.

Med andre ord er finansieringssystemet i foretakene $\mathrm{i}$ all hovedsak knyttet til kun én av de lovpålagte oppgavene sykehusene har, nemlig pasientbehandlingen. De andre oppgavene: forskning, utdanning og opplæring av pasienter og pårørende, utløser ingen inntekter på denne måten. Samtidig er det en forutsetning i innsatsstyrt finansiering at alle utgiftene til foretakene skal dekkes innenfor den økonomiske rammen, også spesialiseringen av leger. Mens inntektene til foretakene er knyttet til pasientbehandlingen, er den største utgiftsposten i budsjettet personalkostnadene. Derfor er antall DRG-poeng per legeårsverk blitt en hyppig brukt styringsparameter som målfester effektiv drift, eller mangel på sådan. Jo flere DRGpoeng en lege kan produsere, jo bedre er driften.

Slike styringsmål påvirker spesialiseringen av leger. Enkelte har hevdet at effektivitet er blitt det mest sentrale i lege-pasient-forholdet (2). Jon Magnussen har spurt retorisk om det finnes noen situasjoner der det er gunstig med et «ineffektivt lege-pasient-forhold» (3)? Jeg vil svare et rungende JA på det spørsmålet. Spesialiseringen av leger er et godt eksempel på et område der et effektivt lege-pasient-forhold har direkte ugunstige effekter som kommer til å straffe seg på sikt.

Supervisjonen, eller mester-svenn-læring, er kjernen i spesialisering av leger. Under supervisjon utfører en lege i spesialisering legearbeid mens en mer erfaren lege, helst en spesialist, overvåker og instruerer. Med utgangspunkt i antall DRG-poeng per legeårsverk er dette per definisjon ineffektiv pasientbehandling. I streben etter kostnadseffektiv produksjon erfarer vi derfor at slike læringssituasjoner forsvinner.

Veiledningen av leger i spesialisering er et element i den formaliserte delen av spesialiseringen. Under veiledningssamtalen skal legen i spesialisering og veilederen trekke seg vekk fra den daglige driften og ikke bidra til produksjon, men bruke tid på refleksjon og samtale. Dette er nok et eksempel på gunstig, men ineffektiv bruk av leger sett med bedriftsøkonomiske øyne.

Forslag til kutt i legers arbeidstid er et hyppig brukt kostnadsreduserende virkemiddel. Arbeidstidskuttene er ofte innrettet slik at viktige møtepunkter og læringsarenaer som for eksempel morgenmøter, rapportmøter eller røntgenmøter rammes. Men antall DRGpoeng per legeårsverk øker når arbeidstid kuttes.
En av de virkelig store endringene i norsk sykehusdrift de siste 10-20 årene er overgangen fra døgnbehandling til poliklinisk behandling. Mens utredning og behandling av pasienter tidligere foregikk over flere dager på en sengepost, gjennomføres dette nå poliklinisk eller som dagbehandling i planlagte pasientforløp. Jeg mener dette er en riktig utvikling, men det har konsekvenser for spesialiseringen av leger. Flere av spesialiseringsarenaene, og ikke minst pasientkategoriene, har forsvunnet fra hverdagen til legen i spesialisering uten at dette er blitt kompensert.

Fra politisk hold settes søkelyset på ventelister og uakseptabel lang ventetid. I opptakten til den kommende valgkampen er private helsetilbud allerede satt på agendaen. Økte private tilbud foreslås som tiltak for å redusere ventetider og da særlig til polikliniske konsultasjoner. Avtalespesialistene våre er en del av det offentlige helsevesenet og behandler pasienter etter avtale med de regionale helseforetakene innenfor de samme finansieringsordningene som helseforetakene. Avtalespesialistene ønsker å bidra i spesialiseringen, men foreløpig drives det ikke systematisk spesialisering i den private delen av spesialisthelsetjenesten. De helprivate aktørene opererer fritt og utenfor offentlig styring av helseressurser. Det eksisterer ikke avtaler om, og heller ikke insentiver til, å drive spesialisering av leger i disse virksomhetene.

Om flere oppgaver flyttes ut av helseforetakene og over til private aktører, er konsekvensen at en større del av pasientbehandlingen gjøres i virksomheter uten det samme utdanningskravet som helseforetakene er pålagt. De private aktørene vil ikke overta pasienter fra alle pasientkategorier, kun visse diagnosegrupper og prosedyrer. Med økt bruk av private helsetilbydere kan flere pasientgrupper og prosedyrer forsvinne fra de etablerte utdanningsarenaene og dermed svekke utdanningsgrunnlaget slik spesialiseringen gjennomføres i dag.

Når man under omstillinger endrer på eller fjerner spesialiseringsarenaer eller innholdselementer i spesialiseringen, må dette kompenseres. Konsekvenser for spesialiseringen må utredes i forbindelse med omstillinger, men ikke minst når overordnede rammer endres eller nye politiske føringer settes ut i livet. Spesialisering koster og jakten på flest mulig DRG-poeng per legeårsverk går utover kvaliteten på spesialiseringen. Den kortsiktige gevinsten på den økonomiske bunnlinjen vil ikke være verdt prisen når effektene av kvalitetsforringet spesialisering slår inn. Den fulle effekten av dette kommer ikke når kostnadene kuttes, men kanskje 10-15 år senere. Hvor lenge kan helseforetakene holde varmen ved å tisse i buksene?

\section{Johan Torgersen \\ johan.torgersen@legeforeningen.no}

Johan Torgersen (f. 1974) er leder for Yngre legers forening og sitter også i Legeforeningens sentralstyre. Han er spesialist i anestesiologi og har en ph.d. fra det intensivmedisinske fagområdet.

Forfatter har fylt ut ICMJE-skjemaet og oppgir ingen interessekonflikter.

\footnotetext{
Litteratur

1. Støre JG. Politiske mål og forventninger til spesialisthelsetjenesten. Tale til sykehusene 30.1. 2013. www.regjeringen.no/nb/dep/hod/aktuelt/taler_artikler/ minister/taler-og-artikler-av-helse--og-omsorgsmi/2013/politiske-mal-ogforventninger-til-spesi.html?id=713002 (15.4.2013).

Hem E. Vi blir tilfreds til slutt. Tidsskr Nor Legeforen 2013; 133: 5.

3. Magnussen J. Styringsideologi og dokumentasjon. Tidsskr Nor Legeforen 2013; 133: 496.
} 